\title{
Training of Hydraulic Engineers in Germany
}

\author{
Uwe Drewes and Klaus Römisch (*)
}

\section{Introductory Remarks}

In principle, traditional German university education directs training towards the conditions and requirements of practical engineering. With this principle being valid beyond the year 2000 , forecasting future curricula will lead to some contradictions.

First, the requirements of hydraulic engineering practice are subjected to accelerating change. The trends of these developments can not be predicted in detail, in that only principal rules may be forecast.

Second, the state of the art in special areas such as computer application and simulation theories, advances so quickly that it is impossible to design educational programmes for the duration of an entire professional career.

Third, the dramatic change in social values effects the valuation of work done by people in general, and by engineers in particular. This is reflected particularly in the field of hydraulic engineering because engineering structures effect and alter the environment.

Finally, socio-political changes in the world (and especially in Europe) and their potential to reach beyond national boundaries and present mental limits, will impose a significant influence on future training.
In this paper, an educational concept is presented for the expected requirements for hydraulic engineers in the intended United Europe of the year 2000. The authors' point of view reflects predominantly the particular conditions of German universities. However, present problems associated with adaptation and change in the inter-German university system are disregarded as they should be irrelevant after the year 2000 .

\section{Requirements for Hydraulic Engineers in Europe in the Year 2000}

Hydraulic engineers are engineers trained with a basic general study of «Civil Engineering " plus a specialization in the fields of hydromechanics, hydrology, water resources management, and, above all, fluvial hydraulics, dams and weirs, hydro-power, inland navigation, and coastal engineering. Furthermore, the effects of standing, flowing

(*) Prof. Dr.-Ing. Uwe Drewes, Leichtweiß-Institut für Wasserbau, Braunschweig University of Technology.

Prof. Dr. sc. techn. Klaus Römisch, Bereich Wasserbau und Technische Hydromechanik, Dresden University of Technology.

\section{Formation de l'ingénieur hydraulicien en Allemagne}

La formation universitaire de l'ingénieur hydraulicien en Allemagne est liée à la pratique. Les nouveaux domaines sont immédiatement incorporés dans le programme d'études. Actuellement les tâches suivantes gagnent en importance : Compatibilité des ouvrages hydrauliques avec l'environnement. - Maintien, adaptation et assainissement d'ouvrages hydrauliques existants. - Sûreté de la conception et analyse du risque de rupture des ouvrages hydrauliques. - Traitement électronique de l'information et CAO/EAO.

La formation universitaire dure de cinq à six années. Elle consiste en général en trois parties : études théoriques de base; études du génie civil général ; spécialisation dans le domaine du génie civil d'ouvrages hydrauliques et autres domaines analogues.

Pour le futur les buts suivants sont visés: l'ingénieur hydraulicien doit agir comme coordinateur pour assurer la coopération de tous les spécialistes impliqués dans le projet d'un aménagement hydraulique, ceci supposant une coopération inter-disciplinaire avec biologistes, chimistes, écologistes, économistes, etc. ; il doit travailler dans tous les pays européens et doit parler plusieurs langues universelles. 
and percolating water on the environment which have been caused and influenced by hydraulic structures, play an ever-increasing role (1), (2).

The fields of activity of hydraulic engineers may, therefore, be postulated as follows :

- Activities of hydraulic engineers affect nearly all aspects of a society, and sometimes have a lasting influence on it. Salient examples, even if sometimes with poor results, are : intensive river training during the last century and at the beginning of the 20th century; reservoir systems for water supply, irrigation and hydro-power generation ; canals and harbours; dike systems for land reclamation and for protection against disastrous storm surges; irrigation and drainage systems for an improved agriculture. Of course, the interactions between man - technology environment should be regarded in all measures and activities respectively.

- More than in other fields of engineering, responsibility for the natural environment will have to have a high rank during professional education. Knowledge of environmental impact assessment is essential.

- Hydraulic structures often have a transnational character as their effects are not confined to regional or state boundaries. The intended aim of a United Europe opens new and fascinating possibilities. Educational concepts have to consider and to develop these future conditions. - The need for the use and judgment of hydrologic data as well as the need for assessment of the chemistry of waters and of hydro-biological processes, makes clear that scientific foundations relating to various natural sciences are an indispensable component of a future-oriented education. Whatever their actual field of activity, hydraulic engineers will work at initial planning, feasibility studies, tender and final design, the execution and supervision of construction work, water-resources management, as engineers for operation and maintenance, or in administrative positions at various levels. A small, especially talented and interested number will also work in research. Thus preconditions for research should be considered in the educational concept, but may not actually effect its form. The primary task of professional education for hydraulic engineers is to be oriented towards the needs of practical engineering.

Requirements for future hydraulic engineers can therefore be deduced from trends in employing companies, institutions and administrations on the one hand, and from the environment-changing, transregional and scientific character of hydraulic engineering on the other hand. In detail this requirements can be summarized as follows :

- The main subject for hydraulic engineers, water in its numerous appearances, is one of the most precious resources on earth. Therefore, the main field of activity for a hydraulic engineer is to ensure a stable and sustainable water supply with reasonable water-resources management controlling quantity and quality of the water supplied.

- As a result of continuous industrialization and urbanization, new tasks will increasingly appear in the fields of waste-water management and waste-disposal techniques, as well as in the field of sanitation of contaminated rivers, aquifers and fills. Therefore, hydraulic engineers have to lend a hand in order to solve the challenging problems in an interdisciplinary team.

- Many hydraulic structures were built during the first half of our century. As these structures are very expensive and durable, reconstruction measures, alterations due to changing demands and sanitation of entire schemes (in order to obtain a new working life of fifty, eighty or hundred years) will gain importance (4).

- Large hydraulic structures such as dams, weirs and dikes often represent a high risk potential. New safety planning, risk analyses and design of structures for extreme conditions (including the results of global changes in climate) are future tasks of hydraulic engineers.

- The reasonable use of computer based planning and design (CAD/CAE systems) is of increasing importance. However, it should be noted that these systems can support but not replace the creative and constructive activity of the engineers. They are and will always be no more than tools.

- Construction and consulting tasks abroad will increase especially in the field of hydraulic engineering. Therefore, knowledge of foreign languages is an essential requirement.

- With the integrated planning and construction of large projects, civil engineers - and in this case hydraulic engineers - have often to assume the role of generalists in the sense of coordinating and integrating the multiple and detailed tasks (3). An ability and readiness for interdisciplinary cooperation is thus highly necessary. This anticipates the sensitivity of hydraulic engineers to a close cooperation with biologists, chemists, ecologists, landscape planners, economists, etc. (4).

- As hydraulic engineering often causes extensive effects altering the environment, hydraulic engineers in particular have to be conscious of assuming responsibility in the interactions between man - technology - environment (4). According to (5), the task is to develop a reasonable and sustainable standard of living for the earth's population without exhausting the resources of the planet.

\section{Fundamentals for an Educational Concept}

In Germany, hydraulic engineers will be trained on two different levels (6) :

- The Technical College (Fachhochschule) provides mainly practical knowledge and skills with a minimum of scientific background. The duration of that training is four years.

- The University (Universität) and the University of Technology (Technische Universität and Technische Hochschule respectively) provide broad and detailed knowledge, in theory and practice, based on scientifictechnical methods, in order to enable future engineers to solve difficult problems creatively. This training should last, in general, approximately five years. 
Only the educational concept of the latter (subsumed under the term "university") will be discussed in the following. Because of the characteristic requirements discussed before under consideration of general problems, the following focal points can be deducted:

- Basic and general training at university level, sometimes also called initial training, should be designed as widely as possible to ensure that a speedy acquaintance of different subjects is possible. The aim of a university is not to train specialists in that early stage of education (1).

- Only the sequence of university education, getting acquainted with practical problems in the company or agency, on-the-job-training and post-graduate courses represents the scope of professional training. The experienced specialist (expert) is a result of that sequence (7).

- Future-oriented educational concepts have to take into account the responsibility of hydraulic engineers for society and environment, by considering special knowledge as well as general socio-ethical topics in the curriculum. These kind of problems should also be considered in postgraduate education.

- Problems of water-resources and hydraulic engineering in the third world will play an increasingly important role. In future. more and more hydraulic engineers should be prepared to work at least for a part of their professional life in countries of the third world.

- Because of its central geographical position in Europe, Germany will have an influence on the solution of transnational water resources problems (e.g. protection of the Baltic Sea and the North Sea, sanitation and management of the large river systems of Rhine, Danube, Elbe, Oder). By 1993 the European Common Market will become operational and present a great new challenge for engineers (5). University education will have to take this into account by additional language courses and by importing transnational standards. For example, the German standards are also transferred specially adapted to the Eurocode.

Hydraulic engineers have to work with confidence in all European countries and need to speak several main languages. Problems of technical adaptation as well as mutual recognition of test and acknowledgement procedures have to be solved (8).

These four focal points were the subject of numerous discussions at several German universities. These discussions were summarized in respective educational documents and advices, e.g. (3), (4), (6), (9), (10).

On the occasion of a meeting of a group of German full professors for hydraulic engineering, held at the Braunschweig University of Technology in April 1990, these general ideas considered. The following theses for a future educational concept represent a first summary of this discussion :

- The continuing development of the course programme according to the state of the art represents a permanent task. University research accompanying practice-oriented training supports this process. This is the origin of the individual emphasis on the scope of training at each university in Germany - bound up with the personality of the respective professors with regard to experience, teaching and research. This stimulates the variety of individually offered courses but also preserves a wide general education.

- Fundamental training, which also in future should only be the responsibility of universities, has to be designed such that a wide, theoretically oriented basic knowledge is transmitted to the student. With it, after a short exposure period, the graduates should be able to work in all areas of the course programme.

- Based on a regular education of about 10 semesters, the following system was established at various German universities for professional education in hydraulic engineering according to tradition and experience (see e.g. (6) and (9)) :

\section{Basic Courses ( 3 to 5 Semesters)}

- Mathematical Foundations.

- Fundamentals Pertaining to Natural Science.

- Fundamentals of Civil Engineering.

- Basic Hydromechanics.

- Data Processing.

- Foreign Languages.

\section{General Courses (3 to 4 Semesters)}

- General Survey of All Subjects in Civil Engineering.

- Fundamentals of Hydraulic and Water Resources Engineering.

- Economic Appraisal of Hydraulic Engineering Projects.

- Fundamentals of Engineering Hydrology.

- Further Fundamentals of Hydromechanics.

Specialized and Advanced Courses (2 to 3 Semesters)

- Advanced Hydraulic Engineering.

- Advanced Courses in One or Two Other Optional Subjects in Civil Engineering.

- Seminars, Practical Training, Team Works, Students' Excursions, etc...

\section{Thesis (Diplomarbeit) (up to 1 Semester)}

- In addition to tests during the course of each subject, the student has to prove his understanding of interdisciplinary problems in two composite examinations, i.e. the "Diplomvorprüfung" after the Basic Courses, and the "Diplomprüfung" after the Specialized and Advanced Courses.

- The often theoretically oriented Specialized and Advanced Courses have to be supplemented by several study periods with practical contents. They consist of practical courses as well as laboratory tests.

- A practical training programme in engineering of one semester duration, e.g. in the seventh semester, proved to be useful. Always being oriented towards the actual conditions of practice, it gives the student his first practical training. A stronger motivation for advanced studies and even more a reduction in the inevitable period of exposure is expected also in the future from this period of study.

- With all the theoretically oriented presentations of single topics, it has always to be emphasized, that civil engineering projects and thus also hydraulic engineering 
projects (e.g. dams, harbours, canals, irrigation systems, river works) are the result of an integral process of planning and construction. By emphasizing the unity of functional design, constructive solution and technological realization of a project in special courses, a contribution towards avoiding the often observed error of young graduates in starting with detailed calculations instead of doing a preliminary design is given (3).

- In this connexion, independent experimental work is of high significance. Hydraulic laboratories existing at most universities should be used more often for the training of students. By experimental work on his own, the student gains advanced knowledge. The establishment of such teaching complexes will additionally gain an increased importance to counteract the often observed " computerfaith " of graduates, by offering an illustrative founded counter weight. The sometimes mentioned reproach, that young engineers can not think because of computers, can be refuted by this (11).

- The hydraulic engineer especially has to be prepared for the engineer's responsibility for environment and society by courses in social sciences and humanities (9), e.g. as part of a "studium generale». Language courses and special courses about hydraulic problems associated with the European integration as well as developing problems of the third world will gain in importance.

- Oral and written presentation, which are a requirement for a successful leadership and coordination role claimed in (2), have to be developed already during the course. Student seminars and open project discussions are occasions, which should be used for that. Basic theoretical courses and courses in biology, ecology, project evaluation, business administration should supplement the curriculum.

- Universities assume increasing responsibility for further qualification of practicing engineers. Offers of continuing education, e.g. by ways of continuing correspondence courses (see (1)), should present new methods and new ways of understanding. Focal points of such courses could be : environmental protection and its technology, landfill and waste problems, new design and safety concepts, structural sanitation, water protection and water-resources management strategies, mathematical simulation, computer application, measuring and control techniques.

The thoughts presented here can only be a suggestion for educational concepts which, especially adapted, will develop individually at respective universities in Germany. The authors have refrained from presenting specific course programmes of their universities, because these are marked by tradition and individual conditions and can not be regarded as a standard for all the other institutions.

\section{Summary}

Starting with a forecast of the requirements for hydraulic engineers in the year 2000, under the conditions of the European Market, four focal points of a practically relevant education were formulated. These are :

- Wide initial training at universities.

- Initial training, acquaintance on the job and specific continuing education should be regarded as a unity.

- The responsibility of the engineers for society and environment is increasingly demanded and should be part of the university education.

- Problems of water-resources and hydraulic engineering will have an increasing transnational character. Engineers will have to be prepared for the new tasks resulting from this.

\section{References}

[1] Möllemann J.W. - Studien- und Berufschancen für Ingenieure im gemeinsamen europäischen Markt Bund der Ingenieure für Wasserwirtschaft, Abfallwirtschaft und Kulturbau (BWK) e.V. Referate des Jahreskongresses 1989, Münster, Mai 1989.

[2] NAudAscher E. - Neue Lehr- und Forschungsziele in der Hydraulik. Die Wasserwirtschaft, Juli 1971.

[3] DudDECK H. - Entwicklungstendenzen im Bauingenieurwesen Mitteilungen der Technischen Universität Braunschweig, Heft III/1989

[4] Drewes U. - Wasserbau und Gewässerschutz - Bewußtseinswandel und Perspektiven. Mitteilungen der Technischen Universität Braunschweig, Heft II/1990.

[5] Tschöltsch H. - Ingenieure in freien Berufen - Beitrag und Verantwortung für eine intakte Umwelt Bund der Ingenieure für Wasserwirtschaft, Abfallwirtschaft und Kulturbau (BWK) e.V. Referate des Jahreskongresses 1989, Münster, Mai 1989.

[6] - Studienführer für das Studium des Bauingenieurwesens an der Technischen Universität Carolo-Wilhelmina zu Braunschweig. Braunschweig, September 1988.

[7] Plate E. - Die Wasserwirtschaft der Zukunft - eine Herausforderung an die Universitäten. Die Wasserwirtschaft, Januar 1987.

[8] WITTKÄMPER G.W. - Ingenieure from Öffentlichen Dienst - Aufgaben, Leistung, Anspruch. Bund der Ingenieure für Wasserwirtschaft, Abfallwirtschaft und Kulturbau (BWK) e.V. Referate des Jahreskongresses 1989, Münster, Mai 1989.

[9] - Zur Neugestaltung des Studiums an der Technischen Universität Dresden. Dresdner Universitätsjournal, 2/1990.

[10] RöııCH K. - Studienkonzeption der Fachrichtung Wasserbau. Technische Universität Dresden, Juni 1990.

[11] LuCKNer E. - Der Bauingenieur Fritz Leonhardt. Frankfurter Allgemeine Zeitung, Magazin, 6. Juli 1990. 